\title{
Platelet-rich plasma intra-articular injections as an alternative treatment for knee osteoarthritis: a systematic review
}

\author{
Elena SîRBU ${ }^{1}$, Șerban GLIGOR ${ }^{2}$, Corina PANTEA ${ }^{3}$
}

\begin{abstract}
Knee osteoarthritis is a degenerative joint disease characterized by cartilage degeneration and hypertrophic lesions of the epiphyseal bone. It is a disabling condition that causes difficulties of locomotion and severe complications in case of inappropriate treatment. There is growing evidence proving the beneficial effects of using platelet-rich plasma (PRP) in the treatment of knee osteoarthritis.

The aim of the present paper is to review the recent scientific literature on the treatment of knee osteoarthritis with plateletrich plasma presenting the current opinion on this subject. Methods: We analys several studies about PRP who were identified using online databases: EBSCO, ScienceDirect, Scopus and PubMed. Results: After the primary analysis we selected a total of 23 relevant studies. The analysis focused on different PRP administration techniques and methods used in knee osteoarthritis. Conclusions: PRP is most widely used in incipient and moderate symptomatic knee osteoarthritis. Most studies show a significant decrease in pain and significant improvement in joint functionality. These results were mostly obtained after a short follow-up period ( 6 months-1 year) and also this treatment has a small number of side effects.
\end{abstract}

Key words : platelet-rich plasma (PRP), knee osteoarthritis, pain, function, range of motion

\section{Rezumat}

Osteoartrita genunchiului este o boală degenerativă articulară, caracterizată prin degenerarea cartilajului și leziuni hipertrofice ale epifizei osoase. Este o condiție care determină dizabilitate, care cauzează dificultăți de deplasere și complicații severe în caz de tratament necorespunzător. Există dovezi importante care probează efectele benefice ale utilizării terapiei cu plasmă îmbogățită cu trombocite (PRP) în tratamentul osteoartritei genunchiului.

Scopul prezentei lucrări este de-a trece în revistă datele științifice recente din literatură privind tratamentul osteoartritei genunchiului cu PRP și de-a prezenta opinia curentă asupra acestui subiect. Metode: Am analizat câteva studii despre PRP, care au fost identificate folosind căutarea online prin intermediul unor baze de date cum ar fi: EBSCO, ScienceDirect, Scopus și PubMed. Rezultate: După analiza primară am selectat 23 de studii relevante despre subiect. Analiza s-a centrat pe tehnicile diferite de administrare a PRP și pe metodele folosite în tratamentul osteoartritei genunchiului. Concluzii: PRP este folosit în principal în osteoartrita simptomatică a genunchiului, incipientă sau moderată. Majoritatea studiilor arată o scădere semnificativă a durerii și o îmbunătățire semnificativă a funcționalității articulației. Aceste rezultate s-au obținut în special după o scurtă perioadă de urmărire (6 luni - 1 an) și totodată această metodă terapeutică are un număr redus de efecte secundare.

Cuvinte cheie: plasmă îmbogățită cu trombocite (PRP), osteoartrita genunchiului, durere, funcție, limita de mișcare

\footnotetext{
${ }_{1}^{1}$ Associate Professor, MD, PhD, West University of Timisoara, Physical Education and Sport Faculty, Romania, email: elena.sirbu@e-uvt.ro

${ }^{2}$ Associate Professor, MD, PhD, West University of Timisoara, Physical Education and Sport Faculty, Romania

${ }^{3}$ Associate Professor, MD, PhD, West University of Timisoara, Physical Education and Sport Faculty, Romania
} 


\section{Introduction}

Osteoarthritis $(\mathrm{OA})$ is the most common joint pain and a leading cause of chronic disability in people over 50 years old, with a huge socio-economic impact which turns it into a public health problem. The prevalence of knee $\mathrm{OA}$ is $9 \%$ in individuals older than 30 years andincreases 2 to 10 -fold from age 30-65 years [1].

The pathogenesis of knee osteoarthritis is complex and includes degradation and repair processes of the cartilage and subchondral bone with synovial inflammation. Hence, OA affects the entire joint including cartilage, synovia, subchondral bone, ligaments and muscles.

The exact causes are not fully known but several factors including mechanical stress, biochemical and genetic factors were identified. The hallmark of this process lies on the chondrocytes response to injuries by producing degradation enzymes and by developing inappropriate repair responses. Enzymes such as proteinases and proinflammatory cytokines are responsible for cartilage damage but also for other tears [2].

Most patients complain about pain and decreased range of motion (motion $\mathrm{ROM}$ ) in the affected joint which can progress to full ankylosis and therefore can significantly impair the quality of life.

According to the EULAR recommendations, optimal management requires both non-pharmacological and pharmacological management of pain [3]. Over time several studies were conducted on the benefits of oral and parenteral drugs in knee OA but the results were unsatisfactory.

Nonsteroidal anti-inflammatory drugs, glucosamine, chondroitin-sulphate, hyaluronic acid (HA) and glucocorticoids have been proposed for pain reduction, mobility improvement, and disabilitybut the results were controversial.

Recent studies have highlighted the importance of platelet-rich plasma (PRP) in tissue regeneration due to growth factors that are contained in platelets (alpha granules). Several experimental studies were conducted on PRP effects including the positive effects on cartilage, bone, synovia and ligaments [48].

Platelet-rich plasma (PRP) is a concentrate of plasma, rich in platelets that are obtained from centrifuged whole blood and therefore without red blood cells. There are four categories of PRP preparations based on the leukocyte and fibrin content: leukocyte reduced or pure PRP (P-PRP), leukocyte-rich PRP (L-PRP), leukocyte and plateletrich fibrin (L-PRF) and pure platelet-rich fibrin (PPRF) [9].

The aim of the present paper is to review the recent scientific literature on the use of PRP intra-articular injections in knee osteoarthritis, to present the different administration techniques and methods.

\section{Metods}

Several studies were identified using the following online databases: EBSCO, ScienceDirect, Scopus and PubMed. Searches were limited to full-text Englishlanguage journal articles published between 2010 and 2017 using the following key words: platelet rich plasma, knee osteoarthritis, synovial fluid, proteins, muskuloskeletal ultrasound, MRI. Limits regarding language (i.e., English), age (i.e., adults), and humans were taken into account.

Three reviewers screened abstracts and full-text articles and applied the eligibility criteria in order to identify studies that were appropriate for inclusion. A study was included if (a) the abstract was available, (b) it contained original data, (c) it used accepted classification criteria for knee osteoarthritis, (d) it discussed the use of PRP for intra-articular injections and its efficacy in the treatment of knee OA. Articles were excluded if they were case reports, if they discussed topics not related to knee $\mathrm{OA}$, if they did not meet the inclusion criteria, if they had insufficient data, or if they had results that showed lack of statistical significance.

\section{Search results}

The collected literature focused on PRP and the use of PRP for intra-articular injections in knee osteoarthritis.

After the primary analysis we selected a total of 23 relevant studies. The analysis focused on different PRP administration techniques and methods used in knee OA. Although the outcome measurements in these studies varied significantly, all of them used conventional pain, function and quality of life scales. Also, the volume of blood used for PRP preparations, methods of PRP preparations, presence of white blood cells, administration 
protocol of knee injections, and other functions varied significantly between studies.

\section{Discussion}

One of the most important uses of PRP injections is in early, symptomatic knee osteoarthritis (OA). A lot of studies have been carried out recently on the benefic effects of this type of treatment.

Huang P.H. et al. [10] carried out a retrospective study on 127 patients (191 knee joints), in which they compared different injection methods for PRP (once a month, two times per month, and three injections at one month interval). Evaluation of results was carried out 12 months after the last PRP injection by using the following scales: VRS scale ("Visual Rating Scale"), ROM ("Range of Motion"), WOMAC score, IKDC score ("International Knee Documentation Committee"), and the functional score. After a 12 month follow-up period all the patients showed significant improvement in comparison to previous determinations. Statistically significant differences only appeared in the group that received three injections at one month interval. This group presented significant improvement in pain, functional score and WOMAC score. Although, all three treatment groups presented improvement of the studied parameters, the radiological exam after 12 months of PRP injections showed no significant changes in the $\mathrm{OA}$ Ahlback staging [10].

Hassan A.S. et al. [11] published a study that evaluated the effects of PRP injections in 20 patients diagnosed with primary osteoarthritis (OA). $5 \mathrm{ml}$ PRP were injected monthly in each affected joint for 6 months in a row. The treatment response was evaluated at the end of the 6 month period using the IKDC score ("International Knee Documentation Committee"), VAS score (visual Analogue Scale for pain), and ultrasonography. The group concluded that: (a) synovial hypertrophy was reduced in $75 \%$ of the cases (confirmed by ultrasound); (b) joint pain (tenderness at the joint line) was significant reduced ( $\mathrm{p}<0.05$ ); (c) ROM improved significantly; (d) IKDC score and VAS score improved significantly $(\mathrm{p}<0.001)$ [11].

Another study carried out by Chen C. et al. evaluated the impact of PRP injections on incipient and moderate $\mathrm{OA}$, associated with superolateral bursitis [12].
The criteria included in this study were the following:

- The width of the superolateral bursa over $2 \mathrm{~mm}$ confirmed by musculoskeletal ultrasound.

- A history of intra-articular infiltration therapy of the knee or NSAIDs consumption without the reduction of the synovial fluid or of the pain.

- $\mathrm{OA}$ is the cause for the superolateral bursitis.

- Chronic pain and inflammation of the knee for at least 6 months.

- A communication between the superolateral bursa and the synovial space of the knee confirmed by ultrasound.

After applying the inclusion criteria they selected a group of 24 patients. These patients received the PRP treatment as follows: $5 \mathrm{ml}$ PRP in one injection/month for 3 months. The response to treatment was evaluated through the total protein concentration in the synovial fluid $(\mu \mathrm{g} / \mu \mathrm{l})$, measurement of the fluid quantity $(\mathrm{ml})$, and through the functional index (LeQuesne). This evaluation was carried out after each injection, at 3 and at 6 months from the third injection. After the administration of 2 doses of PRP they observed a decrease in the total protein concentration, synovial fluid, and functionality index. The authors considered that a minimum of 2 PRP injections are needed for the treatment of minor to moderate $\mathrm{OA}$ with superolateral bursitis [12].

The PRP injections represents a relatively new way of treatment in osteoarthritis and degenerative lesions of the knee. It is considered to be a simple method, minimally invasive and with low costs that brings important advantages in the therapy of these pathologies [13].

Controversy still exists regarding the administration ways of PRP injections and regarding the optimal treatment protocol. Several clinical studies have proven a positive response after only one PRP injection [4].

On the other hand, Halpren B. et al. (cited by McCarrel T.M., et al.) have followed through clinical evaluation and MRI the effects of PRP injection on the progression of knee OA. $[15,16]$. The results of this study showed a significant decrease in pain, appreciated through the VAS scale ("Visual Analogue Scale"), at 6 months and one year after therapy, as well as a significant increase in the WOMAC parameters, pain, rigidity, and ADL scores. 
Concurrently, MRI showed no deterioration in the patelofemural $\mathrm{OA}$ in the majority of the patients, which suggests that the PRP treatment can play an important role in the treatment of primary OA. [15, 16].

However, the efficacy of PRP treatment in OA is not yet completely elucidated, a limitation being the fact that clinical studies carried out so far were in majority series of case reports, with a small number of patients, and that there are still very few reports of randomized controlled trials [17].

Hereafter, Çaliş H.T. et. al. [18] followed the effects of PRP therapy on pain, functional status and cartilage regeneration. Inclusion (chronic knee pain in the last year, daily chronic knee pain for the last month, VAS score $>5$, degenerative OA stage $3-4$, unresponsive to NSAIDs treatment) and exclusion criteria were applied resulting in a group of 82 patients. These patients received three injections with $3 \mathrm{ml}$ of PRP at one week interval. Evaluation of therapy effects were carried out at the beginning of the treatment, at 1 week, 2 weeks, and after this at 3 and 6 months. Pain was evaluated using the VAS score, functional status was evaluated using the WOMAC score, and cartilage regeneration by musculoskeletal ultrasound.

This study showed significant improvement in all the followed parameters $(\mathrm{p}<0.05)$ compared to starting values. Therefore, they concluded that using PRP injections as a treatment for OA is a minimally invasive method that is also safe and efficient even in the 3 - 4 stages of OA.

Among these studies we also found the study by Laudy A.B.M et al. [19] that carried out a systematic literature research regarding the applications of PRP in OA, using the most well-known data bases in the world, until June 2014, and selected a number of 371 articles. After applying their inclusion and exclusion criteria 14 full text articles were analyzed. The results of these papers showed a significant decrease in pain and an improvement in function when the results were compared with a placebo or with the hyaluronic acid injection [19].

Also, another review article by Zhu Y. et al. [20] concluded that applying PRP therapy in OA has promising short term results (1-2 years). However, there are certain limitations of this conclusion because most of the studies were not controlled randomized trials. Moreover, there are certain limitations given by the quality of the platelets used in the PRP concentrate that can have an influence on the action, as well as by the different methodologies used by each analyzed study and the different preparation methods for the PRP [20].

Short-term effects of the PRP therapy in knee osteoarthritis were studied by Saegusa A.W. et al. [21] in a prospective, longitudinal study on a group of 312 patients diagnosed with OA. There were 3 PRP injections administered at a 2 week interval. The VRS scale ("Visual Rating Scale"), the WOMAC score, the LeQuesne index and the SF-36 were used for the evaluation of the patients before and 6 months after the last injection. After a 6 month follow-up period all patients showed significant improvement $(\mathrm{p}<0.0001)$ in comparison to previous values. The results of this study prove the efficacy of PRP therapy and assert choosing it as a first line treatment for knee osteoarthritis (OA). [21].

In another review study, De La Mata J. (22) concluded that the PRP method is a relatively new therapeutic tool, with good compliance among patients and good short-term efficacy that was proven in the literature, especially for knee osteoarthritis and epicondylitis. For these pathologies PRP is unanimously approved as therapy [22].

Ankle OA is also a possible use of PRP injections. In a retrospective study from 2017 Repetto I. et al. [23] followed the clinical results of 20 patients with ankle OA (with a mean age of 57.5), over a mean period of 17.7 months. PRP was administered through 4 injections of $3 \mathrm{ml}$, once a week, without using anesthetics. The results showed a significant improvement in joint functionality (evaluated through FADI-"Foot and Ankle Disability Index") and a significant decrease in local pain, evaluated by VAS ("Visual Analogue Scale"). Moreover, 80\% of the patients were satisfied with the treatment and were capable of returning to previous levels of activity. However, although this study shows the benefits of PRP in ankle OA, it has some limitations, these being the retrospective character of the study, the small number of subjects, and the relatively short monitoring time (17.7 months) [23]. 


\section{Conclusions}

- PRP is most widely used in incipient and moderate symptomatic OA of the knee.

- Regarding the administration protocol of PRP injections the most widely used is: 1 intraarticular injection/month for 3 months.

- Studies that have used this protocol obtained significant decrease in pain and significant improvement in joint functionality. These results were mostly obtained after a short follow-up period (6 months-1 year).

- Because the PRP is an autologous medication it has a small number of side effects.

- Further randomized controlled clinical trials are needed, with a bigger number of patients, in order to prove the efficacy of PRP treatment in osteoarthritis and other pathologies.

\section{References}

1. Manek N.J., Lane N.E. (2000). Osteoarthritis: current concepts in diagnosis and management, Am. Fam. Physician, 61, 1795-1804.

2. Felson D.T., Lawrence R.C., Dieppe P.A., et. al. (2000). Osteoarthritis: new insights. Part1: the disease and its risk factors. Ann. Intern Med., 133, 635-646.

3. Pendleton A., Arden N., Dougados M., et al. (2000), EULAR recommendations for the management of knee osteoarthritis: report of a task force of the Standing Committee for International Clinical Studies Including Therapeutic Trials (ESCISIT), Ann Rheum. Dis., 59, 936-944.

4. Hayami T. (2008). Osteoarthritis of the knee joint as a cause of musculoskeletal ambulation disability symptom complex (MADS), Clin. Calcium, 18,1574-80.

5. Filardo G., Kon E., Roffi A., Di Matteo B., Merli M.L., Marcacci M. (2015). Platelet-rich plasma: why intraarticular? A systematic review of preclinical studies and clinical evidence on PRP for joint degeneration, Knee Surg. Sports Traumatol. Arthrosc., 23(9), 2459-2474.

6. Sakata R., McNary S.M., Miyatake K., et al. (2015). Stimulation of the superficial zone protein and lubrication in the articular cartilage by human plateletrich plasma, Am. J. Sports Med., 43(6), 1467-1473.

7. Osterman C., McCarthy M.B., Cote M.P., et al. (2015). Platelet-rich plasma increases anti-inflammatory markers in a human coculture model for osteoarthritis, Am. J. Sports Med., 43(6), 1474-1484.

8. Almasry S.M., Soliman H.M., El-Tarhouny S.A., Algaidi S.A., Ragab E.M. (2015). Platelet rich plasma enhances the immunohistochemical expression of platelet derived growth factor and vascular endothelial growth factor in the synovium of the meniscectomized rat models of osteoarthritis, Ann. Anat., 197, 38-49.

9. Dohan Ehrenfest D.M., Rasmusson L., Albrektsson T. (2009). Classification of platelet concentrates: From pure platelet-rich plasma (P-PRP) to leucocyte- and platelet-rich fibrin (L-PRF), Trends Biotechnol., 27, 158-167.

10. Huang P-H, Wang C-J, Chou W-Y, Wang J-W, Ko J-Y, (2017). Short-term clinical results of intra-articular injections for early osteoarthritis of the knee, International Journal of Surgery, 42, 117-122.

11. Hassan A.S., Abeer Mohamed El-Shafey A.M., Ahmed H.S., Hamed M.S. (2015), Effectiveness of the intraarticular injection of platelet rich plasma in the treatment of patients with primary knee osteoarthritis, The Egyptian Rheumatologist, 37(3), 119-124.

12. Chen C.P.C., Cheng C.H., Hsu C.C., Lin H.C., Tsai Y.R., Chen J.L. (2017). The influence of platelet rich plasma on synovial fluid volumes, protein concentrations, and severity of pain in patients with knee osteoarthritis, Exp. Gerontol., 93, 68-72.

13. Kon E., Buda R., Filardo G., Di Martino A., Timoncini A., Cenacchi A., Fornasari P.M., Giannini S., Marcacci M. (2009). Platelet-rich plasma intraarticular knee injections produced favorable results on degenerative cartilage lesions, Knee Surg. Sports Traumatol. Arthrosc., 18(4), 472-9.

14. Lansdown D.A., Fortier L.A. (2017). Platelet-rich plasma: formulations, preparations, constituents, and their effects, Operative Techniques in Sports Medicine, 25, 7-12.

15. Halpren B., Chaudhury S., Rodeo S.A., et al. (2013), Clinical and MRI outcomes after platelet-rich plasma treatment for knee osteoarthritis, Clin. J. Sport Med., 23(3), 238-239.

16. McCarrel T.M., Mall N.A., Lee A.S., Cole B.J., Butty D.C., Fortier L.A. (2014), Considerations for the use o platelet-rich plasma in orthopedics, Sports Med., 44: 1025-1036.

17. Simental-Mendía M.A., Víichez-Cavazos J.F., MartínezRodríguez H.G. (2015). El plasma rico en plaquetas en osteoartrosis de rodillla: una alternative de tratamiento. Articulo de revisíon, Cirurgía y Cirujanos, 83, 352-358.

18. Çaliş H.T., Sütbeyaz S.T., Güler E., Halici C., Sayan H., Koç A., Konk M., Yazicioğlu J.A. (2015), Efficacy of Intra-Articular Autologous Platelet Rich Plasma Application in Knee Osteoarthritis, Arch. Rheumatol., 30(3), 198-205.

19. Laudy A.B.M., Bakker E.W.P., Rekers M., Moen M.H. (2015), Efficacy of platelet-rich plasma injections in osteoarthritis of the knee: a systematic review and meta-analysis, Br. J. Sports Med., 49, 657-672.

20. Zhu Y., Yuan M., Meng H.Y., Wang A.Y., Guo Q.Y., Wang Y., Peng J. (2013). Basic science and clinical application of platelet-rich plasma for cartilage defects and osteoarthritis: a review, Osteoarthritis and Cartilage, 21, 1627-1637.

21. Saegusa A.W., Cugat R., Ares O., Seijas R., Cusco X., Garcia-Balletbo M. (2011). Infiltration of plasma rich in growth factors for ostheoarthritis of the knee short term effects on function and quality of life, Arch. Orthop. Trauma Surg., 131, 311-317.

22. De La Mata J. (2013). Plasma rico en plaquetas: un nuevo tratamiento para el reumatologo? Reumatol. Clin., 9(3), 166-171. 
23. Repetto I., Biti B., Cerruti P., Trentini R., Felli L. (2017).

Conservative treatment of ankle osteoarthritis: can platelet-rich plasma effectively postpone surgery?, The Journal of Foot \& Ankle Surgery, 56, 362-365. 